\title{
Antimalarial herbal drugs: a review of their interactions with conventional antimalarial drugs
}

\author{
Earnest Oghenesurwe Erhirhie ${ }^{1 *}$ (D) Chidozie Ikegbune ${ }^{2}$, Anthony Ifeanyi Okeke ${ }^{3}$, \\ Chukwunonso Chukwudike Onwuzuligbo ${ }^{4}$, Ngozi Ukamaka Madubuogwu' ${ }^{1}$, Uche Maryann Chukwudulue ${ }^{5}$ and \\ Onyinye Blessing Okonkwo ${ }^{6}$
}

\begin{abstract}
Development of resistance by malaria parasites to conventional antimalarial drugs has rejuvenated the exploration of herbal medicine as alternatives. Also, the increasing rate of the use of herbal antimalarial remedies in combination with conventional antimalarial drugs (both synthetic and semi-synthetic) has inspired researchers to validate their herb-drug interaction effects. This review evaluated the interaction outcomes between herbal antimalarial drugs in combination with conventional antimalarial drugs. With the aid of electronic databases, Pubmed and Google scholar, articles related to this subject were sourced from English peer reviewed scientific journals published from 2003 to 2020. Search terms used include "antimalarial-herbal drugs interaction", "antimalarial medicinal plant interactions with conventional antimalarial drugs", "drug-herbal interactions, "antimalarial drugs and medicinal plants". Synergistic, antagonistic and none effects were reported among 30 studies reviewed. Among 18 in vivo studies on P. berghei and P. yoelii nigerense infected mice model, 14 showed synergism, 3 showed antagonism and 1 involving three plants showed both effects. Among 9 in-vivo studies involving normal animal (non-infected), 2 showed antagonism, 2 showed synergism and 5 showed none-effects. Two (2) studies on human volunteers and one (1) in vitro quantitative study showed that Garcinia kola reduced plasma concentrations of quinine and halofantrine. Generally, majority of herbal antimalarial drugs showed synergistic effects with CAMDs. Vernonia amygdalina was the most studied plant compared to others.

Consequently, herbal remedies that produced synergistic effects with conventional antimalarial drugs may be prospects for standardization and development of antimalarial-medicinal plant combination therapy that could curtail malaria resistance to conventional antimalarial therapies.
\end{abstract}

Keywords: Pharmacokinetics, Antimalarial-herb drug interaction, Medicinal plants, Combination therapy, Efficacy

\section{Introduction}

\section{The malaria encumbrances}

Malaria is a parasitic disease caused four major species of Plasmodium including Plasmodium falciparum (P. falciparum), Plasmodium vivax, Plasmodium malariae and Plasmodium ovale. Among these species, P. falciparum

\footnotetext{
* Correspondence: erhirhieochuko@yahoo.com

${ }^{1}$ Department of Pharmacology and Toxicology, Faculty of Pharmaceutical Sciences, Chukwuemeka Odumegwu Ojukwu University, Igbariam, Nigeria Full list of author information is available at the end of the article
}

still remains the most harmful [1]. In the sub-Saharan Africa, Asia, and Latin America, malaria produces significant levels of mortality and morbidity [2].

On a yearly basis an estimated proportion of 3 billion persons are exposed to malaria, while about 1.2 billion people are at high risk [3]. In tropical countries, malaria remains the most prevalent disease presenting more than 219 million symptomatic cases and 435,000 projected deaths, as revealed by recent statistics $[3,4]$. The African region has been known to have the highest cases 
as well as deaths, with pregnant women and children under five years being the most vulnerable groups [5].

Following bites from female anopheles mosquitoes, Plasmodium parasites journey through the bloodstream, get matured and then reproduce in the liver, which eventually manifest malaria typical symptoms such as headache, fever, weakness, pain, nausea, abdominal distress, and excessive perspiration [2]. Prolonged and untreated cases of malaria could lead to complications such as severe anemia, brain tissue damage, kidney failure, pulmonary edema and yellow discoloration of the skin [6].

Although significant achievements have been made contending malaria, it has become worrisome following discovery of the resistance strains of $P$. falciparum against artemisinin combination therapies (ACTs), the prominent antimalarial agents [3].

\section{Conventional antimalarial drugs and their limitations}

Chemotherapy remains the primary therapeutic approach in the control of malaria [7], and antimalarial agents exist as single or combination therapies. Those in the single category and their respective classes in parenthesis include Quinine (Cinchona alkaloid), Amodiaquine (AQ), Piperaquine and Chloroquine, (CQ) 4aminoquinolines), Primaquine (8-aminoquinolines), Pyrimethamine (Diaminopyrimidines), Sulfadoxine (Sulfonamides), Artesunate (ART) and Artemeter (Sesquiterpine lactones), Mefloquine (Quinoline-methanol), Lumefantrine and Halofantrine (Amino alcohols), Atorvaquone (Naphthoquinone) and Proguanil (Biquanides). Combination therapies encompass nonartemisinins such as Sulfadoxine + Pyrimethamine, Sulfadoxine + pyrimethamine + amodiaquine, among others, and artemisinins which include ART + amodiaquine, ART + meflquine, Artemether + lumefantrine, ART + sulfadoxine/pyrimethamine, among others $[6,8]$.

Some limitations observed for non-artemisinin antimalarial drugs include compromise of efficacy [9], high cost and their ability to cause toxicity leading to low patients' compliance [10]. Nonetheless, the greatest challenge facing antimalarial drugs is the emergence of resistance [11] which prevails because; several of these antimalarial agents are chemically related. A case in point is the cross resistance between 4-aminoquinolines, $\mathrm{CQ}$ and AQ [12]. Prior to the emergence of resistance, CQ was an efficient and affordable antimalarial drug of choice $[9,13]$. However, artemisinin and its semisynthetic derivatives produced better effectiveness than quinine [14] and this led to the recommendation of artemisinin and its derivatives, artemisinin-based combination therapy (ACTs) as current first-line drugs against malaria caused by P. falciparum infection [3, 10]. Notwithstanding the recommendation of the ACTs as current antimalarial frontline therapy in most tropical countries, artemisinin-resistant Plasmodium parasites still prevail in some parts of the world $[6,13]$, and this calls for more researches on more effective and safer alternatives.

\section{Medicinal plants as alternatives to conventional antimalarial drugs}

Medicinal plants have played significant roles in the treatment of malaria and have been recommended in curbing resistance posed by Plasmodium parasites to conventional antimalarial drugs $[15,16]$. Traditionally, herbal medicine remains the backbone for the treatment of malaria for over thousands of years. The first antimalarial drug (quinine) was isolated from the bark of the Cinchona tree, in the family of Rubiaceae, an herbal medicine. In the early 1632, an infusion of the Cinchona bark was used for the treatment of human malaria [1]. Artemisia апnиa is another earliest millennial medicinal plant that was rediscovered in China from which artemisinin was isolated [1]. Potentials of herbal medicine have stirred up scientific concerns in the investigation of novel antimalarial drugs from natural products, which remains an effective approach in malaria control [17]. Indeed, herbal medicine is gaining popularity in developed as well as developing countries due to their affordability, accessibility, acceptability and availability [16].

Studies from 2001 to 2017 showed that about 2000 plant-derived compounds exhibited antimalarial activity against $P$. falciparum [6].

\section{Antimalarial drugs-antimalarial medicinal plant combination therapy}

There is a reliance on the practice of the concomitant use of herbal antimalarial with conventional antimalarial drugs, as a result of the occurrence of resistance as well as high patronage and high confidence in the effectiveness of herbal remedies $[13,17]$. This approach is applied by some patients as an avenue to increase efficacy, and also facilitate compliance [11]. Though this may be without recourse to the possibility of antagonistic effect which may result from such herb-drug interaction. Such combination practice is very common in malarial endemic countries (the tropical regions) where conventional antimalarial drugs are expensive and cannot be afforded by some rural dwellers $[18,19]$. Combination therapy $(\mathrm{CT})$ is even recommended to ensure enhanced efficacy and diminution of resistance by parasitic strains [11].

Usually, there are instances of self-medication where some patients receive herbal medicines, before proceeding for conventional medicines, without revealing to physicians that they have been on such herbal medicine, thereby increasing the chances of herbal-drug interaction [13]. The use of herbal therapies before, during 
(concomitantly) and after conventional antimalarial drugs is not left out of this practice.

The practice of concomitant application of conventional antimalarial drugs and herbal antimalarial drugs is not only limited to the poor and uneducated, but the rich and the learned are also involved [20]. Indeed, these practices have their therapeutic implications, as pharmacokinetics or pharmacodynamics interactions of such drugs could be antagonistic, additive or synergistic [3]. However, the emerging clinical impact of Pharmacists through the due Pharmaceutical care process recommends hope with positive patients' outcome [21].

Researchers, knowing the implications of herb-drug interactions with respect to increasing rates of combination of herbal remedies with conventional antimalarial drugs have taken responsibilities to unravel the possible effects that could result from such interaction. It is also obvious that the potential interaction of conventional drugs with herbs is rarely given important attention by most Physicians [3, 11, 13]. Some researchers have reviewed interactions between herbs and conventional drugs [22] but none have specifically looked into antimalarial herbal remedies and conventional antimalarial drugs as is attempted in this review.

\section{Method}

Information that formed the content of this review was gotten from peer-reviewed English articles published from 2003 to 2020 in scientific journals with the help of electronic databases, such as PubMed and Google Scholar. Search terms used include "antimalarial-herbal drugs interaction", antimalarial medicinal plant interactions with conventional drugs", "drug-herbal interactions, "antimalarial drugs and medicinal plants, and herbal antimalarials and synthetic antimalarials". Articles that met the scope of the topic under consideration were selected for the review. References of selected articles were further checked for titles that match the study context. Inclusion criteria include in-vivo studies involving animal induced with malaria and treated with plant extracts alongside conventional antimalarial drugs, in-vivo studies involving animal or human volunteers without malaria but were administered plant extracts and conventional antimalarial drugs, and in-vitro quantitative studies on the concentration of conventional antimalarial drugs following their combination with medicinal antimalarial plants. Exclusion criteria involved noninteraction studies, where plant extracts were not combined with conventional antimalarial drugs.

Following the increasing rate of drug-herb interaction, the outcome of this review would update researchers on the effects of herbal antimalarial-conventional antimalarial interaction and their clinical implications in malaria therapy.

\section{Interaction studies on herbal-conventional antimalarial drugs}

The use of herbal medicines (HM) is on the rise among the global population, and when in combination with prescription or over-the-counter medications and certain foods, could either increase or decrease the therapeutic outcomes of the conventional drugs [23].

Medicinal plants, unlike conventional drugs are made up of several chemical constituents. Additionally, the chemical makeup of medicinal plants varies depending on the part of the plant used, climate, growing conditions, harvesting, and storage conditions. Several studies have shown that some medicinal plants could alter some pharmacokinetic parameters of conventional antimalarial drugs, consequently increasing or decreasing their efficacy [24].

\section{Results}

Interaction between antimalarial herbal drugs (AHDs) and complementary antimalarial drugs (CAMDs) revealed 8 antagonism, 16 synergism, 5 non-effects and 1 of both effects, making up a total of 30 studies reviewed. The three broad categories of such studies evaluated include interaction between AHDs and CAMDs using $P$. berghei and $P$. yoelii nigerense model, interaction between AHDs and CAMDs in normal animals (mice, rats and rabbits), and interaction between AHDs and CAMDs in human volunteers and in-vitro model. Vernonia amygdalina was the most studied herbal remedy compared to others. Frequencies of CAMDs used include chloroquine $(14,48.28 \%)$, artesunate $(9,30.00 \%)$, amodiaquine $(4,13.79 \%)$, quinine $(2,6.90 \%)$ and halofantrine $(1,3.45 \%)$.

\section{Synopsis of studies on herbal-antimalarial drugs interactions in P. berghei model}

Studies in this category involved Plasmodium berghei ( $P$. berghei) infected mice model which is an acceptable and a reproducible experimental model for screening potential antimalarial candidates. The outcomes of these studies are summarized in Tables 1 and 2.

Recently, Ihekwereme et al [25] did a study on the interaction between artemisinin combination-based therapies; ART and Vernonia amygdalina (VA) methanol leaf extract. The study revealed dose dependent antagonism of ART on the antimalarial efficacy of VA $(125 \mathrm{mg} /$ $\mathrm{kg}$ ) using Rane's curative test in P. berghei. Concomitant administration of $125 \mathrm{mg} / \mathrm{kg}$ of VA and of 35.14 and $2.86 \mathrm{mg} / \mathrm{kg}$ of ART produced parasitemia clearance of $80.49 \%$ and $97.05 \%$ respectively. The authors postulated that people should discourage the combination of the higher dose of ART and VA, and also encouraged the combination of low dose of ART $(2.86 \mathrm{mg} / \mathrm{kg})$ and 125 $\mathrm{mg} / \mathrm{kg}$ of VA in malaria patients. 
Table 1 Summary of studies on herbal-antimalarial drugs interactions using P. berghei model

\begin{tabular}{|c|c|c|c|c|}
\hline $\begin{array}{l}\text { S/ } \\
\text { no }\end{array}$ & Medicinal plant & $\begin{array}{l}\text { Conventional } \\
\text { antimalarial drug }\end{array}$ & Interaction effect & Reference \\
\hline 1 & Methanol leaf extract of VA (125 mg/kg) & $\begin{array}{l}\text { ART }(2.86 \text { and } 35.14 \\
\mathrm{mg} / \mathrm{kg}\end{array}$ & High dose of ART antagonized VA & [25] \\
\hline 2 & $\begin{array}{l}\text { Gynostemma pentaphyllum and Moringa oleifera }(500,1000 \\
\text { and } 2000 \mathrm{mg} / \mathrm{kg} \text { ) }\end{array}$ & ART $(6 \mathrm{mg} / \mathrm{kg})$ & Greater antimalarial activity was recorded. & [10] \\
\hline 3 & Kaempferol (20 mg/kg) & CQ (10 mg/kg) & $\downarrow$ in parasitemia & {$[5]$} \\
\hline 4 & $\begin{array}{l}\text { Aqueous root extract of Cryptolepis sanguinolenta ( } 36 \text { mg/ } \\
\mathrm{kg} \text { ) }\end{array}$ & ART (2.5 mg/kg) & Extract $\downarrow$ effectiveness of ART. & [13] \\
\hline 5 & $\begin{array}{l}\text { Hydroalcoholic fruit extract of Balanites aegyptiaca and leaf } \\
\text { latex of Aloe camperi }\end{array}$ & CQ (12.5 mg/kg) & $\uparrow$ in parasitemia suppression ability of CQ & [23] \\
\hline 6 & $\begin{array}{l}\text { Aqueous fresh leaf extract of } A \text {. indica }(100,500 \text {, and } 1000 \\
\mathrm{mg} / \mathrm{kg})\end{array}$ & $\begin{array}{l}\text { ART }(6,15 \text {, and } 20 \\
\mathrm{mg} / \mathrm{kg})\end{array}$ & A significant reduction in parasitemia & [26] \\
\hline 7 & $\begin{array}{l}\text { Methanol extracts of } 15 \text { Kenya medicinal plants, from } 11 \\
\text { families }\end{array}$ & $\begin{array}{l}\text { CQ (Dose not } \\
\text { specified) }\end{array}$ & Improved suppressions of parasitemia & [27] \\
\hline 8 & Hot water extract of 18 Kenya medicinal plants & $\begin{array}{l}\text { CQ (Dose not } \\
\text { specified) }\end{array}$ & Improved suppressions of parasitemia & [28] \\
\hline 9 & $\begin{array}{l}\text { Aqueous extracts of Morinda morindiodes (Mm) root, } \\
\text { Morinda (MI) lucida leaf and VA leaf }\end{array}$ & ART (10 mg/kg) & $\begin{array}{l}\text { Mm and Ml extract } \downarrow \text { effectiveness of ART, but } \\
\text { ART } \uparrow \text { effectiveness of VA }\end{array}$ & [29] \\
\hline 10 & 216 extracts from 50 Western Ghats plants & $\begin{array}{l}\text { CQ (Dose not } \\
\text { specified) }\end{array}$ & Moderate to high in vivo antimalarial activity & [30] \\
\hline 11 & Carica papaya leaf (50 mg/kg) & ART (15 mg/kg) & Antagonism & [31] \\
\hline
\end{tabular}

Vernonia amygdalina (VA); Artesunate (ART); Plasmodium berghei (P.berghei); Chloroquine (CQ). $\downarrow$ (Decreased activity), $\uparrow$ (Increased activity)

In a separate study, the chemotherapeutic interaction between VA $(100-500 \mathrm{mg} / \mathrm{kg})$ and Amodiaquine, AQ (2-10 $\mathrm{mg} / \mathrm{kg})$ and ART $(0.8-4 \mathrm{mg} / \mathrm{kg})$ was investigated in P. berghei infected swiss albino mice. Sub-therapeutic doses of 100 , 2 and $2.4 \mathrm{mg} / \mathrm{kg}$ were obtained for VA, AQ and AR respectively. The study revealed a significant increase in the chemosuppressive effect of AQ and ART, as well as parasite clearance when co-administered with VA extract. Also, the mean survival period was higher in animals that received the three combinations, VA, AQ, AR compared to placebo [3].
An investigation was carried out on the antimalarial activity of kaempferol $(20 \mathrm{mg} / \mathrm{kg})$ when combined with CQ $(10 \mathrm{mg} / \mathrm{kg})$. A reasonable antimalarial activity with prolonged survival time of $P$. berghei strain infected mice was recorded for Kaempferol alone and in combination with CQ. Notably, the effect produced by kaempferol was not significantly different from that of the $C Q$ treated group. Suppression at the combined doses (20 and $10 \mathrm{mg} / \mathrm{kg}$ ) ranged from 70 to $95.98 \%$ in suppressive, prophylactics and curative tests [5].

Table 2 Summary of studies on herbal-antimalarial drugs interactions using $P$. berghei and $P$. yoelii nigerense model

\begin{tabular}{|c|c|c|c|c|}
\hline $\begin{array}{l}\text { S/ } \\
\text { no }\end{array}$ & Medicinal plant & $\begin{array}{l}\text { Conventional antimalarial } \\
\text { drug }\end{array}$ & Interaction effect & Reference \\
\hline 12 & Aqueous leaf extract of TO $(200$ mg/kg) & ART (2 mg/kg) & Synergistic effect & [16] \\
\hline 13 & VA (100-500 mg/kg) & $\begin{array}{l}\text { AQ }(2-10 \mathrm{mg} / \mathrm{kg}) \text { and ART } \\
(0.8-4 \mathrm{mg} / \mathrm{kg})\end{array}$ & Synergistic effect & [3] \\
\hline 14 & $\begin{array}{l}\text { Aqueous leaf extract of Ageratum conyzoides } \\
(100 \mathrm{mg} / \mathrm{kg})\end{array}$ & CQ $(5 \mathrm{mg} / \mathrm{kg}), \mathrm{ART}$ & Extract potentiated activities of CQ and ART & [32] \\
\hline 15 & $\begin{array}{l}\text { MAMA herbal antimalarial decoction (120 mg/ } \\
\mathrm{kg} \text { ) }\end{array}$ & AQ $(10 \mathrm{mg} / \mathrm{kg})$ & $\begin{array}{l}\text { Synergistic effect against CQ sensitive (except } \\
\text { resistant) }\end{array}$ & [33] \\
\hline 16 & $\begin{array}{l}\text { Methanol leaf extract Uvaria chamae }(100-400 \\
\mathrm{mg} / \mathrm{kg})\end{array}$ & AQ $(10 \mathrm{mg} / \mathrm{kg})$ & $\begin{array}{l}\text { Low dose of extract }+\mathrm{AQ} \text { produced better } \\
\text { antimalarial activity }\end{array}$ & [34] \\
\hline 17 & $\begin{array}{l}\text { Aqueous leaf extract of VA }(31.25,62.5,125 \mathrm{mg} / \\
\mathrm{kg})\end{array}$ & CQ (5 mg/kg) & Extract $\uparrow$ antimalarial effects of CQ & [15] \\
\hline 18 & $\begin{array}{l}\text { Ethanol stem bark extract of Khaya grandifolia } \\
(50-400 \mathrm{mg} / \mathrm{kg})\end{array}$ & $\begin{array}{l}\mathrm{CQ}(2.5 \mathrm{mg} / \mathrm{kg}) \\
\text { Halofantrine, } 6.25 \mathrm{mg} / \mathrm{kg})\end{array}$ & $\begin{array}{l}\text { Enhanced antiplasmodial activity and mean } \\
\text { survival time }\end{array}$ & [11] \\
\hline
\end{tabular}

Vernonia amygdalina (VA); Artesunate (ART); Plasmodium berghei (P. berghei); Chloroquine (CQ). Amodiaquine (AQ). $\uparrow$ (Increased activity) 
In a 4-day suppressive test using $P$. berghei on the extract of Gynostemma pentaphyllum and Moringa oleifera at 500,1000 and $2000 \mathrm{mg} / \mathrm{kg}$ produced dose dependent suppression of 45,50 , and $55 \%$ and 35,40 , and $50 \%$ respectively. Greater antimalarial activities with suppression of 78, 91, and $96 \%$ for G. pentaphyllum leaf extract and 73,82 , and $91 \%$ of Moringa oleifera leaf extract were observed when they were combined with ART $(6 \mathrm{mg} /$ $\mathrm{kg})$. The authors recommended that their combination with ART showed a strong prospect for development as antimalarial combination therapy [10].

The outcome of co-administration of the hydroalcoholic fruit extract of Balanites aegyptiaca and leaf latex of Aloe camperi on the antimalarial effect of CQ was investigated by Sibhat and Hiben [23] using peters four day suppressive method in $P$. berghie infected mice. The study revealed that Balanites aegyptiaca and leaf latex of Aloe camperi increased the parasitemia suppression ability of CQ.

Adepiti et al., [33] investigated the effect of concomitant administration of AQ and MAMA herbal antimalarial decoction, comprising leaves of Mangifera indica, Alstonia boonei, Morinda lucida and Azadirachta indica in CQ-sensitive P. berghei. There was a complete parasite clearance in the therapeutic combination dose (MAMA, $120 \mathrm{mg} / \mathrm{kg}$ and Amodiaquine, $10 \mathrm{mg} / \mathrm{kg}$ ) against CQ -sensitive P. berghei. Conversely, remarkable activity was not recorded at these doses against CQresistant $P$. berghei.

Adepiti and Iwalewa [34] also investigated possible herbal interaction of Uvaria chamae methanol leaf extract $(100-400 \mathrm{mg} / \mathrm{kg})$ with AQ $(10 \mathrm{mg} / \mathrm{kg})$ in mice infected with CQ-sensitive $P$. berghei in in four -day, curative and prophylactic antimalarial test models. CQ -resistant $P$. berghei mice were also treated with extract at $400 \mathrm{mg} / \mathrm{kg}$ and AQ in the four-day prophylactic and curative test models. The interaction study revealed that low-dose combination of the leaf extract and AQ produced a better antimalarial activity in the CQ-sensitive murine malaria, but not in CQ-resistant murine malaria.

In other to evaluate the interaction effect between ART and Cryptolepis sanguinolenta, Ocloo and coworkers administered aqueous root extract of Cryptolepis sanguinolenta $(36 \mathrm{mg} / \mathrm{kg})$ and ART $(2.5 \mathrm{mg} / \mathrm{kg})$ in $P$. berghei infected male Sprague-Dawley rats. The study revealed that the extract reduced the effectiveness of ART following concurrent administration. It was recommended that this combination could lead to ART inactivity against malaria. Thus, patients who practice the use of the combination should take caution [13].

In vivo schizontocidal activity in swiss albino mice infected with malaria parasite using the aqueous fresh leaf extract of Azadirachta indica at 100, 500, and $1000 \mathrm{mg} /$ $\mathrm{kg}$ and 6,15 , and $20 \mathrm{mg} / \mathrm{kg}$ of artesunic acid alone and in combination were investigated. A significant reduction in parasitemia at $96.87 \%$ was recorded at $1000 \mathrm{mg} /$ $\mathrm{kg}$ of the extract combined with $15 \mathrm{mg} / \mathrm{kg}$ of artesunic acid when compared to $68.14 \%$ reduction produced by $20 \mathrm{mg} / \mathrm{kg}$ of artesunic acid alone. The artesunic acid did not produce a cure on day 30, except the combinations of both the extract with artesunic acid [26].

Adegbolagun et al [16] investigated the effect of aqueous leaf extract of Telfaria occidentalis on the biological activities of ART using a curative model in P. berghei infected mice. The study revealed that the extract, ART and the combination of both produced $72.17 \pm 4.07 \%$, $70.43 \pm 4.27 \%$ and $85.43 \pm 3.65 \%$ reduction in parasitaemia respectively, after $48 \mathrm{~h}$ of administration, demonstrating a synergistic effect of the combination on parasite clearance of $P$. berghei infection.

A total of 216 extracts from 50 Western Ghats traditionally used to treat malaria were tested for in vivo antiplasmodial activity alone as well as in combination with CQ against CQ-tolerant $P$. berghei strain. The study revealed that more than $70 \%$ of the plant extracts displayed moderate to high in- vivo antimalarial activity when used separately as well as in combination with CQ [30].

Antimalarial properties of fresh Carica papaya leaf $(50 \mathrm{mg} / \mathrm{kg})$ alone and in combination with artesunic acid $(15 \mathrm{mg} / \mathrm{kg})$ were determined by using the Peter's 4-day suppressive test in $P$. berghei -infected mice. From the study, the combination of Carica papaya with artesunic acid was antagonistic. The authors concluded that combinations of artemisinins and Carica papaya show little promise for combination therapy development [31].

In four-day suppressive and curative tests, the effect of aqueous leaf extract of Ageratum conyzoides in combination with CQ and ART was investigated using P. berghei infection in mice. There were greater suppressive activities in both extract-drug combinations, with extract-CQ $(100 \mathrm{mg} / \mathrm{kg}: 5 \mathrm{mg} / \mathrm{kg})$ having the highest suppressive effect (98\%) than individual drugs. Absolute survival was recorded in the two extract-drug combinations than individual drugs. The authors concluded that aqueous extract of Ageratum conyzoides potentiates the antimalarial activity of CQ and ART [32].

Chemotherapeutic interaction between ethanol stem bark extract of Khaya grandifolia $(50-400 \mathrm{mg} / \mathrm{kg})$ and two antimalarial drugs $(\mathrm{CQ}, 2.5 \mathrm{mg} / \mathrm{kg}$ and halofantrine, $6.25 \mathrm{mg} / \mathrm{kg}$ ) in mice infected with Plasmodium yoelii nigerense was carried out. The study revealed enhanced antiplasmodial activity and mean survival time when the extract was combined with CQ or halofantrine compared to individual drugs. The authors posited that reduced therapeutic doses of halofantrine may be needed to enhance parasite clearance when used together with Khaya grandifolia, thereby yielding a great advantage to 
halofantrine which produces cardiotoxicity at high doses [11].

Aqueous leaf extract of VA was found to enhance the antimalarial effects of CQ in CQ sensitive and resistant P. berghe. CQ at $5 \mathrm{mg} / \mathrm{kg}$ was administered in combination with $31.25,62.5,125 \mathrm{mg} / \mathrm{kg}$ of the extract. At 30 $\mathrm{mg} / \mathrm{kg}$ of CQ for 3 days in combination with the extract, there was a decrease in parasite clearance times from 4.8 to 2.6-4.4 days for CQ-VA 62.5/125 combination, prolonged recrudescent times (from 7.2 to 8.9-18.9) and also improved cure rate (from $58.3 \%$ to $66.7-100 \%$ ) in the treated $P$. berghei - infected mice on day 14 compared to CQ monotherapy [15].

Methanol extracts of 15 medicinal plants, from 11 families traditionally used for malaria treatment in Kenya were screened for their in vivo antimalarial activity against a CQ (CQ)-tolerant P. berghei. Following combination of the extract with CQ, Albizia gummifera, Ficus sur, Rhamnus prinoides and Rhamnus staddo, Caesalpinia volkensii, Maytenus senegalensis, Withania somnifera, Ekebergia capensis, Toddalia asiatica and Vernonia lasiopus produced statistically significant and improved suppressions of parasitemia which ranged from 45.5 to $85.1 \%$ compared to when they were used alone (31.7-59.3\%). Remarkable parasitemia suppression by the extracts when used alongside CQ produced longer mouse survival than the control [27].

As a follow up study, hot water extracts of 18 medicinal plants representing five families of plants used in Kenya for treatment of malaria were screened against CQ resistant $P$. berghei either alone or in combination with CQ. A similar result was recorded, as there was outstanding parasitemia suppression by extracts when administered in combination with $\mathrm{CQ}$, which gave rise to longer survival of mice relative to the controls [28].

In the year 2020, Idowu and co-workers evaluated the interaction effects of Morindamorindiodes (Mm) root, Morindalucida (ML) leaf and Vernonia amygdalina (VA) leaf on the efficacy of artemisinin derivatives. From the study, artesunate produced a total parasite clearance (100.00\%). Although the single administration of Mm and ML extracts produced considerable antiplasmodial effects (86.83 and $84.20 \%)$, their combination with artesunate (10 $\mathrm{mg} / \mathrm{kg}$ ) did not produce complete parasite clearance $(89.93$ and $89.43 \%)$. VA in the presence of artesunate produced a better chemosupression $(86.93 \%)$ than when it was administered alone (48.10\%). The authors emphasized the need to educate the public on the likely limitations associated with concomitant use of antimalarial plants alongside conventional antimalarial drugs [29].

\section{Synopsis of studies on herbal-antimalarial drugs interactions with normal animals}

This section is made of pharmacokinetic studies that involved normal animals that were not subjected to $P$. berghei or other forms of malaria infections. Concentrations of standard antimalarial drugs were measured following their co-administration with herbal remedies. The outcome of these studies is summarized in Table 3.

Adepiti and co-researchers explored the influence of MAMA antimalarial decoction $(125 \mathrm{mg} / \mathrm{kg})$ on the pharmacokinetics of AQ $(10 \mathrm{mg} / \mathrm{kg})$ in mice. Using a validated high-performance liquid chromatography (HPLC) approach, blood samples were collected between 0 and $96 \mathrm{~h}$ for quantification of $\mathrm{AQ}$ and its major metabolite (desethylamodiaquine). In the presence of the decoction, there was a $12 \%$ increase in the maximum concentrations of $\mathrm{AQ}$, while the $85 \%$ increase was recorded in mice pretreated for 3 days. An increase was also recorded in the active metabolites. The authors concluded that the decoction influenced the pharmacokinetics of AQ and desethylamodiaquine [39].

Eseyin et al [25] evaluated the effect of Gnetum africana on the pharmacokinetic parameters of CQ phosphate in overnight fasted albino rats. The study revealed a significant decrease in $\mathrm{C}_{\max }(9.17 \%), \mathrm{Ka}(3.06 \%), \mathrm{Ke}$ (45.38\%), $\mathrm{Cl}(48.46 \%)$ and AUC (0-8) (16.90\%) of CQ $(15 \mathrm{mg} / \mathrm{kg})$ by the extract $(200 \mathrm{mg} / \mathrm{kg})$. The $\mathrm{t}_{1 / 2}(83.11 \%)$ and $t_{\max }(100.00 \%)$ of CQ phosphate was increased by the extract. The authors remarked that since the pharmacokinetic parameters of CQ were altered by the extract, malaria patients on CQ treatment should beware of consuming Gnetum africana alongside $C Q$, as such, could lead to a decreased therapeutic effect of the drug thereby leading to resistance.

Eseyin et al [36] did another study on the effects of the leaf extract of VA (250 and $500 \mathrm{mg} / \mathrm{kg}$ ) on the pharmacokinetics of dihydroartemisinin $(2 \mathrm{mg} / \mathrm{kg})$ in rats. UV spectrophotometer was used to measure the serum level of dihydroartemisinin at $0,0.25,0.5,0.75,1.0,2.0$, and 5 $\mathrm{h}$ on the last day (day 7 th) of concurrent dihydroartemisinin and extract administration. There was a reduction in bioavailability (F), absorption constant $(\mathrm{Ka})$, peak concentration $\left(\mathrm{C}_{\max }\right)$ as well as elevation in the apparent volume of distribution $\left(\mathrm{V}_{\mathrm{d}}\right)$. Administration of the extract at a single dose $(250$ and $500 \mathrm{mg} / \mathrm{kg})$ caused a reduction in AUC, as well as an elevation in elimination constant. The authors posited the need for patients receiving VA alongside dihydroartemisinin to exercise caution.

The effect of the aqueous root extract of Cryptolepis sanguinolenta on the pharmacokinetics of ART in male Sprague-Dawley rats was investigated. A single oral dose of ART $(150 \mathrm{mg} / \mathrm{kg})$ was administered after the exposure of animals to $36 \mathrm{~g} / \mathrm{kg}$ of the extract for two weeks. There was an increase of 233 and $62.1 \%$ in the elimination rate constant and clearance of dihydroartemisinin (the most potent metabolite of ART) respectively, when ART was concurrently administered with Cryptolepis 
Table 3 Summary of studies on herbal-antimalarial drug interactions in normal animals (mice, rats and rabbits)

\begin{tabular}{|c|c|c|c|c|c|}
\hline $\begin{array}{l}\text { S/ } \\
\text { no }\end{array}$ & Medicinal plant & $\begin{array}{l}\text { Conventional } \\
\text { antimalarial drug }\end{array}$ & Animal & Interaction effect & Reference \\
\hline 1 & $\begin{array}{l}\text { Aqueous root extract of Cryptolepis } \\
\text { sanguinolenta }(36 \mathrm{~g} / \mathrm{kg})\end{array}$ & ART $(150 \mathrm{mg} / \mathrm{kg})$ & Rats & $\begin{array}{l}\text { Cryptolepis sanguinolenta decreases the } \\
\text { effectiveness of ART }\end{array}$ & {$[35]$} \\
\hline 2 & VA (250 and $500 \mathrm{mg} / \mathrm{kg})$ & $\begin{array}{l}\text { Dihydroartemisinin (2 mg/ } \\
\mathrm{kg})\end{array}$ & Rats & $\downarrow$ in AUC; $\uparrow$ in $\mathrm{Ka}$ & {$[36]$} \\
\hline 3 & Leaf of Heinsia crinata (200 mg/kg) & CQ (15 mg/kg) & Rats & Extract $\downarrow$ bioavailability of CQ & {$[37]$} \\
\hline 4 & Aqueous leaf extract of Azadirachta indica & CQ (Dose not specified) & Rabbit & Extract $\uparrow \& \downarrow$ in pharmacokinetic parameters & [38] \\
\hline 5 & $\begin{array}{l}\text { MAMA herbal antimalarial decoction (120 } \\
\mathrm{mg} / \mathrm{kg})\end{array}$ & AQ (10 mg/kg) & Mice & $\begin{array}{l}\text { Decoction } \uparrow \text { the activity of } \mathrm{AQ} \text { and its } \\
\text { metabolites }\end{array}$ & [39] \\
\hline 6 & $\begin{array}{l}\text { Ethanolic leaf extract of Lasianthera Africana } \\
(200 \mathrm{mg} / \mathrm{kg})\end{array}$ & $\mathrm{CQ}(15 \mathrm{mg} / \mathrm{kg})$ & Rats. & Extract $\uparrow \& \downarrow$ in pharmacokinetic parameters & {$[40]$} \\
\hline 7 & Ethanolic leaf extract of Vernonia amygdalina & CQ $(10 \mathrm{mg} / \mathrm{kg})$ & Rats & Extract $\uparrow \& \downarrow$ in pharmacokinetic parameters & [41] \\
\hline 8 & Grapefruit juice (4 ml/kg) & CQ (100 mg/kg) & Mice & $\uparrow$ plasma concentration of CQ & [42] \\
\hline 9 & Gnetum africana (200 mg/kg) & CQ (15 mg/kg) & Rats & $\uparrow \& \downarrow$ in some pharmacokinetic parameters & [24] \\
\hline
\end{tabular}

Vernonia amygdalina (VA); Artesunate (ART); Plasmodium berghei (P. berghei); Chloroquine (CQ). Amodiaquine (AQ). $\downarrow$ (Decreased activity), $\uparrow$ (Increased activity)

sanguinolenta when compared with ART alone. A significant reduction was recorded in bioavailability (40.1\%), volume of distribution (68.1\%) and half-life (52.1\%) of dihydroartemesinin, indicating that Cryptolepis sanguinolenta could produce decrease in effectiveness due to herb-drug interactions. They suggested the need to inform patients on the serious implication of using Cryptolepis sanguinolenta and ART concomitantly [35].

Effect of ethanol leaf extract of Lasianthera africana on the pharmacokinetic parameters of CQ was investigated. The first group of rats received only CQ $(15 \mathrm{mg} /$ $\mathrm{kg})$, while the second group received the extract (200 $\mathrm{mg} / \mathrm{kg})$ and CQ $(15 \mathrm{mg} / \mathrm{kg})$ at the same time. Using UVVis spectrophotometer, the serum was analyzed for CQ and protein. The extract significantly altered the pharmacokinetic parameters of $\mathrm{CQ}$ as follows; relative increase in $t_{1 / 2}(115 \%), t_{\max }(100 \%), V_{d}(14 \%)$ and AUC (0$\infty)(59 \%)$ and reduction in $\mathrm{K}_{\mathrm{a}}(54 \%), \mathrm{K}_{\mathrm{el}}(53 \%), \mathrm{C}_{\max }$ (38\%) and CL (47) [40].

In 2010, Eseyin and co-workers studied the effects of the leaf of Heinsia crinata on the pharmacokinetics of CQ in rats. CQ $(15 \mathrm{mg} / \mathrm{kg})$ was administered at the same time with the extract $(200 \mathrm{mg} / \mathrm{kg})$ to group one, while only CQ $(15 \mathrm{mg} / \mathrm{kg})$ was administered to the second group. Serum of blood collected via cardiac puncture under chloroform anesthesia in $0.25,0.50,1.00,2.00$, 4.00 and $8.00 \mathrm{~h}$ was analyzed spectrophotometrically at 344 and $260 / 280 \mathrm{~nm}$. The study revealed that concomitant oral administration of CQ and Heinsia crinata extract produced significant $(p<0.05)$ reduction in most as well as a significant increase in few pharmacokinetic parameters of $C Q$. As suggested by the authors, reduced bioavailability of $C Q$ produced by the vegetable extract indicates that a higher dose of $C Q$ may be required whenever the vegetable meal is taken with CQ [37].
The pharmacokinetics interaction effect between ethanolic leaf extract of VA and CQ was studied in rats. The extract was administered before and at the same time with CQ. The study revealed AUC of $297.52 \pm 8.45$ and $333.22 \pm 24.99, C_{\max }$ of $74.60 \pm 1.02$ and $76.60 \pm 3.07$ for test and control groups. Elimination rate $(\mathrm{Ke})$ in the test group $(0.088 \pm 0.035)$ was higher than the control group $(0.027 \pm 0.017)$. The authors recommended the avoidance of concomitant administration of VA and CQ to avoid the development of resistance [41].

Ali et al [42] investigated the effect of grapefruit juice (GFJ) on plasma CQ kinetics in mice. Grapefruit juice $(4 \mathrm{~mL} / \mathrm{kg})$ was orally administered to mice before oral administration of CQ $(100 \mathrm{mg} / \mathrm{kg})$. Measurement of CQ plasma concentration was done fluorometrically at 0 , $0.5,0.75,1,2,3,4,6,8,12,18$ and $24 \mathrm{~h}$ subsequent to its administration. Mean AUC, $\mathrm{C}_{\max }$, and $\mathrm{T}_{\max }$ for control (distilled water) and test (GFJ) were 5.34 \pm 0.38 and $7.01 \pm 0.66 \mathrm{mg} \cdot \mathrm{h} / \mathrm{L} ; 763.4 \pm 39.1$ and $859.2 \pm 45.2 \mathrm{mg} / \mathrm{L}$ and 2.65 and $2.95 \mathrm{~h}$ respectively. The authors concluded that concomitant administration of GFJ with CQ enhances the plasma concentration of $\mathrm{CQ}$,

\section{Synopsis of studies on herbal-antimalarial drugs interactions in-vitro and in human volunteers}

Studies involving in-vitro model as well as human volunteers made up this section and the outcome of these studies are summarized in Table 4.

Igbinoba et al [19] evaluated the interaction between quinine and Garcinia kola (G. kola) using an in vitro adsorption method at $37 \pm 0.1{ }^{\circ} \mathrm{C}$. HPLC was used to quantify the amount of quinine adsorbed and desorbed. From the study, Quinine was adsorbed on G. kola, suggesting the need to circumvent the simultaneous administration of quinine and G. kola. This would aid in preventing 
Table 4 Summary of studies on herbal-antimalarial drugs interactions in human volunteers and in-vitro studies

\begin{tabular}{|c|c|c|c|c|}
\hline $\begin{array}{l}\text { S/ } \\
\text { no }\end{array}$ & Medicinal plant & $\begin{array}{l}\text { Conventional antimalarial } \\
\text { drug }\end{array}$ & Interaction effect & Reference \\
\hline 1 & $\begin{array}{l}\text { Garcinia kola seed }(12.5 \\
\text { g) }\end{array}$ & Quinine sulphate $(600$ mg/kg) & $\downarrow$ in peak plasma concentration of quinine and its metabolites & [43] \\
\hline 2 & Kola nut (12.5 g) & Halofantrine (500 mg) & $\begin{array}{l}\downarrow \text { in plasma concentrations of halofantrine and its active } \\
\text { metabolite }\end{array}$ & [44] \\
\hline 3 & Garcinia kola seed & Quinine: HPLC quantitative study & Quinine was adsorbed on G. kola (indicating antagonism) & [19] \\
\hline
\end{tabular}

Vernonia amygdalina (VA); Artesunate (ART); Plasmodium berghei (P. berghei); Chloroquine (CQ). Amodiaquine (AQ). $\downarrow$ (Decrease activity)

potential drug interaction and decreased drug bioavailability.

In a follow-up study, a randomized crossover study was carried out in 24 healthy Nigerian volunteers to investigate the effect of concurrent ingestion of G. kola seed on the pharmacokinetics of quinine. One group of participants received $600 \mathrm{mg}$ quinine sulphate per subject before and after the administration of G. kola (12.5 g) daily for seven days, while another group received $12.5 \mathrm{~g}$ twice daily for six days and once on day seventh. There was a reduction in the peak plasma concentration of quinine and its metabolites (3 hydroxyquinine) following the Co-administration of oral quinine and G. kola seeds. The authors posited the need for caution to be exercised when oral quinine is given concurrently with G. kola [43].

Kolade et al [44] investigated the effect of kola nut on the pharmacokinetics of halofantrine using 15 healthy male volunteers who received $12.5 \mathrm{~g}$ of kola nut alongside $500 \mathrm{mg}$ of halofantrine. Collected blood samples were analyzed by HPLC. The study revealed a significant decrease in the plasma concentrations of halofantrine and the active metabolite (desbutylhalofantrine). Authors submitted that caution should be exerted whenever halofantrine is taken together with caffeine-containing nutrients.

An interaction study between CQ and aqueous leaf extract of Azadirachta indica was investigated in rabbits. There was a significant decrease in serum concentration of CQ following concurrent administration of both drugs. There was a slower absorption and elimination as well as longer half-life of CQ. Significant reduction in the area under the curve (71.9\%), maximum serum concentration (69.8\%), absorption rate constant (37.3\%), elimination rate constant (53.9\%), clearance rate (76.5\%) and volume of distribution $(47.2 \%)$ as well as pronounced elevation in the half-life of the drug (125.7\%) were observed [38].

Postulated interaction mechanism(s) between medicinal plants and conventional antimalarial drugs

A combination of two or more drugs would either produce a none effect, especially when both drugs do not have interaction. Also, such combination could result to a less effect (antagonism), usually when one of the drugs decreases or abolishes the action of the other. In synergism, the action of one drug is expedited or enhanced by the other drug, resulting in an additive or potentiation effect [45].

It is interesting to note that, the three interaction effects stated above were observed from the above highlighted studies. But what mechanism(s) or process could have underlain such interactions?

Medicinal plants contain various bioactive compounds such as tannins, terpenoids, saponins, alkaloids, coumarins, kaempferol, quinines, flavonoids, chalcones, sesquiterpene lactones, quercetin, sesquiterpenes, polyphenols [10] among others, which are responsible for their antimalarial activities as a well as interaction effects with conventional antimalarial drugs. The presence of plant secondary metabolites could pose significant alterations in pharmacokinetics parameters of the combination [2]. Diminution in pharmacological activity could also result when plant chemicals combine and interact with drug transporters [46]. For instance, zinc can stimulate intestinal proteins that bind drugs and hinder their absorption from the lumen of the intestine into the blood circulation [24]. Also, the half-life of CQ was found prolonged following inhibition of Cytochrome $\mathrm{P}_{450}$ enzymes by flavonoids [24]. Green leafy vegetables have been reported to be among foods which alkalinize urine, which in turn increases tubular reabsorption, leading to a reduction in Ke of CQ [24, 47]. Iwalokun [15] proposed the synergistic action of VA on CQ to be due to the ability of VA to prolong the elimination half-life of CQ. In the same vein, Sibhat and Hiben, [23], suggested that some herbal products could alter some pharmacokinetic parameters of CQ by blocking its absorption, distribution and elimination [23].

Igbinoba and co-researchers in their in vitro study suggested that the interaction of quinine with G. kola could have occurred due to capacity-limited adsorption of quinine unto G. kola, which contains flavonoids that possesses functional groups that promote formation of complexes with other compounds. The presence of trace elements (sodium, magnesium, calcium, copper, aluminum, potassium and zinc) in G. kola was suggested to have the capacity of producing drug interactions via chelation [19]. 
Medicinal plants that are rich in fat and dietary fiber have the capacity of delaying the entry of orally administered drugs [24, 48]. Thus, concomitant administration of plant based food with conventional antimalarial drugs would go a long way increasing or decreasing their therapeutic or adverse effects.

From the review, chloroquine $(14,48.28 \%)$ appeared to have the highest frequency of combination with medicinal plants, which substantiates its affordability and preference of use with herbal medicines by the locals.

Pharmacokinetic parameters such as elimination rate constant (Kel), absorption rate, peak serum concentration, elimination half-life $\left(\mathrm{T}_{1 / 2}\right)$, area under the curve (AUC), volume of distribution (Vd), absorption rate constant $(\mathrm{Ka})$, maximum whole blood concentration $\left(\mathrm{C}_{\max }\right)$, time for maximum concentration to be attained $\left(\mathrm{T}_{\max }\right)$ and clearance $(\mathrm{Cl})$, of a drug can be affected by food and phytoconstituents [13]. Case in point, the activity of cytochrome $\mathrm{P}^{4} 50_{1 \mathrm{~A}}$ isozyme was enhanced following simultaneous administration of $C$. sanguinolenta and ART, which resulted to decrease in bioavailability, halflife, clearance, volume of distribution, increase elimination rate constant of dihyhroartemisinin, the active metabolite of ART [13, 35].

\section{Conclusion and suggestions for further studies}

From the appraised studies, antimalarial efficacies of some conventional antimalarial drugs decreased the effectiveness of some extracts, while some extracts also decreased the effectiveness of some conventional antimalarial drugs.

Indeed, studies on extracts that produced additive effects with conventional antimalarial drugs, suggests prospects for standardization and development of such antimalarial-medicinal plant combination therapy [10]. According to Ijarotimi et al., [11], 100\% survival of animals infected with Plasmodium yoelii nigerense during an interaction study between Khaya grandifolia and halofantrine accentuates the need for combination therapy between conventional antimalarial drugs and medicinal plants.

Although the development of effective and promising combination therapies would go a long way, providing a cost effective approach in the control of malaria resistance, further studies using Plasmodium falciparum strains as well as human volunteers would be required to validate the outcome of animal studies presented in this review. Further mechanism based studies behind conventional antimalarial and antimalarial medicinal plant interactions should be carried out.

\section{Caution}

Evidences presented in this review update are preliminary data and are not projected for self-medication, to supplement or substitute health care givers or clinicians' guidelines. They are for education of the Pharmacists, Physicians and researchers. Thus, adequate consultations should be gotten from well-informed physicians and researchers before their applications.

\section{Abbreviations \\ ACTs: Artemisinin combination therapies; P. falciparum: Plasmodium falciparum; HM: Herbal medicines; P. berghei: Plasmodium berghei; ART: Artesunate; VA: Vernonia amygdalina; CT: Combination therapy; AQ: Amodiaquine; CQ: Chloroquine; $\downarrow$ : Decreased activity; $\uparrow:$ Increased activity}

\section{Acknowledgements \\ Not applicable.}

\section{Authors' contributions}

EOE conceptualized the study and drafted the original manuscript. $\mathrm{Cl}, \mathrm{AlO}$, CCO, NUM, UMC and OBO revised the drafted manuscript for intellectual content. The author(s) read and approved the final version of the manuscript for submission.

\section{Funding}

Not applicable.

Availability of data and materials

Not applicable.

Ethics approval and consent to participate

None.

\section{Competing interests}

Authors have no conflict of interest to declare.

\section{Author details}

${ }^{1}$ Department of Pharmacology and Toxicology, Faculty of Pharmaceutical Sciences, Chukwuemeka Odumegwu Ojukwu University, Igbariam, Nigeria. ${ }^{2}$ Department of Pharmaceutical Microbiology and Biotechnology, Faculty of Pharmaceutical Sciences, Chukwuemeka Odumegwu Ojukwu University, Igbariam, Nigeria. ${ }^{3}$ Department of Clinical Pharmacy and Pharmacy Management, Faculty of Pharmaceutical Sciences, Chukwuemeka Odumegwu Ojukwu University, Igbariam, Nigeria. ${ }^{4}$ Department of Pharmaceutics and Pharmaceutical Technology, Faculty of Pharmaceutical Sciences, Chukwuemeka Odumegwu Ojukwu University, Igbariam, Nigeria. ${ }^{5}$ Department of Pharmaceutical and Medicinal Chemistry, Faculty of Pharmaceutical Sciences, Chukwuemeka Odumegwu Ojukwu University, Igbariam, Nigeria. 'Department of Pharmacognosy and Traditional Medicine, Faculty of Pharmaceutical Sciences, Chukwuemeka Odumegwu Ojukwu University, Igbariam, Nigeria.

Received: 4 August 2020 Accepted: 23 December 2020 Published online: 03 January 2021

\section{References}

1. Adebayo JO, Krettli AU. Potential antimalarials from Nigerian plants: A review. J. Ethnopharmacol. 2011; 133. 289-302.

2. Okello D, Kang Y. Exploring Antimalarial Herbal Plants across Communities in Uganda Based on Electronic Data Evid Based Complement Alternat Med. Volume 2019, Article ID 3057180, 27 pages.

3. Osirime E, Adeyemi OI, Igbinoba SI, Onyeji CO. Chemotherapeutic interaction of Vernonia amygdalina (Delile) leaf extract with Artesunate and Amodiaquine in murine malaria model. J Pharm Res Int. 2020;32(3):15-24.

4. World malaria report. World health organization. Geneva; 2018. (Accessed on 5, May, 2019) Available:http://www.who.int/malaria/public ations/worldmalaria-report-2018/en/.

5. Voravuth S, Awatsada D, Pinanong O. Antimalarial Activity of Kaempferol and Its Combination with Chloroquine in Plasmodium berghei Infection in Mice. Hindawi Journal of Pathogens. Volume 2018, Article ID 3912090, 7 pages. 
6. Pan W, Xu X, Shi N, Tsang SW, Zhang H. Antimalarial activity of plant metabolites. Int J Mol Sci. 2018;19:1382.

7. Kar S, Kar S. Control of malaria Nat Rev: Drug Discov 2010; 9: 511-512,

8. Erhirhie EO. Antimalarial therapies and infertility a comprehensive review. Toxicol Int. 2016;23(2):107-11.

9. Antony HA, Parija SC. Antimalarial drug resistance: an overview. Trop. Parasitol. 2016;6(1):30-41.

10. Voravuth S, Preeyanuch B, Chokdee K, Kittiyaporn D, Panatda B, Butsarat S. Antimalarial Properties of Aqueous Crude Extracts of Gynostemma pentaphyllum and Moringa oleifera Leaves in Combination with Artesunate in Plasmodium berghei-Infected Mice. Hindawi Publishing Corporation Journal of Tropical Medicine Volume 2016, Article ID 8031392, 6 pages.

11. Ijarotimi SO, Agbedahunsi JM, Onyeji CO, Adewumi CO. Chemotherapeutic interaction between Khaya grandifolia (WELW) CDC stem bark extract and two antimalarial drugs in mice. Afr J Tradit Compliment Altern Med. 2010; 7(4):370-6.

12. Patil CY, Katare SS, Baig MS, Doifode SM. Fixed dose combination of Arterolone and Piperaquine: a new prospect in antimalarial therapy. Ann Med Health Sci Res. 2014;4(4):466-71.

13. Ocloo A, Okpattah WE, Quasie O, Sakyiamah MM, Okine LKN. Concurrent administration of aqueous extract of Cryptolepis sanquinolenta reduces the effectiveness of ART against Plasmodium berghei in rats. J Appl Pharm Sci. 2014;4(03):024-8.

14. Zhang YK, Ge M, Plattner JJ. Recent Progress in the synthesis of antimalarial agents. Org Prep Proceed Int. 2012;44:340-74.

15. Iwalokun BA. Enhanced antimalarial effects of chloroquine by aqueous Vernonia amygdalina leaf extract in mice infected with chloroquine resistant and sensitive Plasmodium berghei strains. Afr Health Sci. 2008;8:25-35.

16. Adegbolagun OM, Emikpe BO, Woranola IO, Ogunremi Y. Synergistic effect of aqueous extract of Telfaria occidentalison the biological activities of ART in Plasmodium berghei infected mice. Afr Health Sci. 2013;13(4):970-6.

17. Delgodaa R, Youngerb N, Barretc C, Braithwaitec J, Davisc D. The prevalence of herbs use in conjunction with conventional medicines in Jamaica. Complement Ther Med. 2010;18(1):13-20.

18. Kremsner PG, Krishna S. Antimalarial combinations. Lancet. 2004; 17: 364 (9430): 285-294.

19. Igbinoba SI, Adehin A, Onyeji CO, Akanmu MA, Soyinka JO. In vitro study of interaction between quinine and Garcinia kola. Trop J Pharm Res. 2016; 15(7):1473-8.

20. Adibe MO. Prevalence of concurrent use of herbal and synthetic medicines among outpatients in a mission hospital in Nigeria. Int J Drug Dev Res. 2009;1(1):60-6.

21. Opara AC, David UA, Ehije FOE. Outcome of pharmaceutical care intervention to hypertensive patients in a Nigeria community pharmacy. J Pharm Pract. 2010;14(2):115-22.

22. Izzo AA. Interaction between herbs and conventional drugs: overview of the clinical data. Review, Medi. Princ. Pract. 2012;21:404-28.

23. Sibhat GG, Hiben MG. Consequence of concurrent use of chloroquine and hydroalcoholic extract of Balanites aegyptiaca and leaf leatx of Aloe camperi. The Journal of Phytopharmacology. 2016;5(1):35-7.

24. Eseyin O, Ebong A, Ubobre A, Ekarika J, Udo I. Changes in some pharmacokinetics parameters of chloroquine by Gnetum africana. Maced I Med Sci. 2012a:1857-5773.

25. Ihekwereme CP, Agafuchukwu P, Erhirhie EO. Artesunate antagonizes antiplasmodial activity of Vernonia amygdalina methanol leaf extract in murine model of malaria. A J Physiol Biochem Pharmacol. 2020;10(1):1-6.

26. Anagu OL, Attama AA, Okore VC, Gugu HT, Ngene AA, Esimone CO. "Azadirachta indica extract-artesunic acid combination produces an increased cure rate of Plasmodium berghei-infected mice," Pharm. Biol, 2014; 52(7); 883-889.

27. Muregi FW, Ishih A, Miyase T, Suzuki T, Kino H, Amano T. et al Antimalarial activity of methanolic extracts from plants used in Kenyan ethnomedicine and their interactions with chloroquine (CQ) against a CQ-tolerant rodent parasite, in mice. J Ethnopharmacol 2007: 111(1): 190-195.

28. Muregi FW, Ishih A, Suzuki T, Kino H, Amano T, Mkoji GM, et al. In vivo antimalarial activity of aqueous extracts from Kenyan medicinal plants and their Chloroquine (CQ) potentiation effects against a blood-induced CQresistant rodent parasite in mice. Phytother Res. 2007;21(4):337-43.

29. Idowu OA, Babalola AS, Olukunle J. Antagonistic effects of some commonly used herbs on the efficacy of Artemisinin derivatives in the treatment of malaria in experimental mice. Bull Natl Res Cent. 2020;44:176.
30. Samy K, Kadarkari M. Antimalarial activity of traditionally used Western Ghats plants from India and their interactions with Chloroquine against Chloroquine-tolerant Plasmodium Berghei. Vector Borne Zoonotic Dis. 2011; 11(3):259-68.

31. Onaku LO, Attama AA, Okore VC, Tijani AY, Ngene AA, Esimone CO. Antagonistic antimalarial properties of pawpaw leaf aqueous extract in combination with Artesunic acid in Plasmodium Berghei-infected mice. J Vector Borne Dis. 2011;48(2):96-100.

32. Ukwe CV, Ekwunife O, Epueke EA, Ubaka CM. Antimalarial activity of Ageratum conyzoides in combination with chloroquine and ART. Asian Pac J Trop Med. 2010:412-20.

33. Adepiti AO, Elujoba AA, Bolaji OO. Evaluation of herbal antimalarial MAMA decoction-amodiaquine combination in murine malaria model. Pharm Biol. 2016;54(10):2298-303.

34. Adepiti AO, Iwalewa EO. Evaluation of the combination of Uvaria Chamae (P. Beauv.) and Amodiaquine in murine malaria. J Ethnopharmacol. 2016; 193:30-5.

35. Sakyiamah MM, Ocloo A, Adjimani JP, Sittie A. Effect of aqueous extract of Cryptolepis sanquinolenta on pharmacokinetics of artesunate. Intl J Pharm Sci Drug Res. 2011;3(4):313-8,

36. Eseyin AO, Igboasoiyi CA, Igbo C, Igboasoiyi A, Ekarika J, Dooka B. Effects of the leaf extract of Venonia amygdalina on the pharmacokinetics of dihydroartemisinin in rat. Pharmacologia. 2012;3(12):713-8.

37. Eseyin $\mathrm{O}$, Ebong $\mathrm{A}$, Attih $\mathrm{E}$, Imo U. Effects of the leaf of Heinsia crinata on the pharmacokinetics of chloroquine in rats. IJBPR. 2010;1(2):88-93.

38. Nwafor SV, Akah PA, Okoli CO, Onyirioha AC, Nworu CS. Interaction between chloroquine sulphate and aqueous extract of Azadirachta indica a. Juss (Meliaceae) in rabbits. Acta Pharma. 2003;53(4):305-11.

39. Adepiti AO, Adeagbo BA, Adehin A, Bolaji OO, Elujoba AA. Influence of MAMA decoction, an herbal antimalarial, on the pharmacokinetics of Amodiaquine in mice. Eur J Drug Metab Pharmacokinet. 2020;45(1):81-8.

40. Eseyin O, Ebong A, Anefiok U, Imo U. Changes in the pharmacokinetics of chloroquine by the leaf extract of Lasianthera africana in rats. J Med Plants Res. 2011;5(13):2665-9.

41. Igboasoiyia C, Eseyin OA, Odoma NF. The effect of ethanolic extract of Vernonia amygdalina leaves on some pharmacokinetic parameters of Chloroquine in rats. Res J Pharmacol. 2008:2(2):24-7.

42. Ali BH, Al-Qarawi A, Mousa HM. Effect of grapefruit juice on plasma chlorquine kinetics in mice. Clin Exp Pharmacol Physiol. 2002;29(8):704-6.

43. Igbinoba SI, Onyeji CO, Akanmu MA, Soyinka JO, Pullela SSW, Cook JM, et al. Effect of dehusked Garcinia kola seed on the overall pharmacokinetics of quinine in healthy Nigerian volunteers. J Clin Pharmacol. 2015;55(3):34854.

44. Kolade YT, Babalola CP, Olaniyi AA, Scriba GK. Effect of kolanut on the pharmacokinetics of the antimalarial drug halofantrine. Eur J Clin Pharmacol. 2008;64:77-81.

45. Tripathi KD. Essentials of Medical Pharmacology. 7th edition. 2013; Pg 56-57. Jaypee Brothers Medical Publishers (P) Ltd ISBN: 978-93-5025-937-5.

46. Ioannides C. Drug - phytochemical interactions. Inflammopharmacology. 2003:11(1):7-42

47. Wallace AW, Amsden GW. Is it really ok to take this with food? Old interactions with new twist. J Clin Pharmacol. 2002;42:437-43.

48. Mason P. Drug-food interactions (1) food and medicines. Continuing professional development. Pharm J. 2002;269:571-3.

\section{Publisher's Note}

Springer Nature remains neutral with regard to jurisdictional claims in published maps and institutional affiliations. 